Research article Open Access

\title{
Atm heterozygous deficiency enhances development of mammary carcinomas in p53 heterozygous knockout mice
}

\author{
Seiichi Umesako1, Kae Fujisawa², Sayoko liga1, Nobuko Mori1,3, Masahiro Takahashi1, Doo- \\ Pyo Hong ${ }^{1}$, Chang-Woo Song ${ }^{4}$, Satomi Haga ${ }^{5}$, Syunsuke Imai6, Otsura Niwa7 and \\ Masaaki Okumoto1,3
}

\author{
${ }^{1}$ Graduate school of Agriculture and Biological Sciences, Osaka Prefecture University, Osaka, Japan \\ ${ }^{2}$ Research Institute of New Medicines, Shionogi Pharmaceutical Co., Osaka, Japan \\ ${ }^{3}$ Research Institute for Advanced Science and Technology, Osaka Prefecture University, Osaka, Japan \\ ${ }^{4}$ Korea Research Institute of Chemical Technology, Taejon, Korea \\ ${ }^{5}$ Department of Anatomy, Nara Medical University, Nara, Japan \\ ${ }^{6}$ Nara Prefecture Institute for Hygiene and Environment, Nara, Japan \\ ${ }^{7}$ Radiation Biology Center, Kyoto University, Kyoto, Japan \\ Corresponding author: Masaaki Okumoto, okumoto@riast.osakafu-u.ac.jp
}

Received: 27 Jul 2004 Revisions requested: 17 Sep 2004 Revisions received: 15 Oct 2004 Accepted: 15 Oct 2004 Published: 10 Dec 2004

Breast Cancer Res 2005, 7:R164-R170 (DOI 10.1186/bcr968)

(C) 2004 Umesako et al., licensee BioMed Central Ltd.

This is an Open Access article distributed under the terms of the Creative Commons Attribution License (http://creativecommons.org/licenses/by/ 2.0,) which permits unrestricted use, distribution, and reproduction in any medium, provided the original work is cited.

\begin{abstract}
Introduction Ataxia-telangiectasia is an autosomal-recessive disease that affects neuro-immunological functions, associated with increased susceptibility to malignancy, chromosomal instability and hypersensitivity to ionizing radiation. Although ataxia-telangiectasia mutated (ATM) heterozygous deficiency has been proposed to increase susceptibility to breast cancer, some studies have not found excess risk. In experimental animals, increased susceptibility to breast cancer is not observed in the Atm heterozygous deficient mice $\left(\mathrm{Atm}^{+/-}\right)$ carrying a knockout null allele. In order to determine the effect of Atm heterozygous deficiency on mammary tumourigenesis, we generated a series of $\mathrm{Atm}^{+/-}$mice on the $p 53^{+/-}$background with a certain predisposition to spontaneous development of mammary carcinomas, and we examined the development of the tumours after $\mathrm{X}$-irradiation.
\end{abstract}

Methods BALB/cHeA- $p 53^{+/-}$mice were crossed with MSM/ $\mathrm{Ms}-\mathrm{Atm}^{+/-}$mice, and females of the $\mathrm{F}_{1}$ progeny ([BALB/cHeA $\times$ $\mathrm{MSM} / \mathrm{Ms}] \mathrm{F}_{1}$ ) with four genotypes were used in the experiments. The mice were exposed to X-rays ( $5 \mathrm{~Gy} ; 0.5 \mathrm{~Gy} / \mathrm{min}$ ) at age 5 weeks.

Keywords: Atm, mammary carcinoma, mouse, $p 53$, radiation
Results We tested the effect of haploinsufficiency of the Atm gene on mammary tumourigenesis after $X$-irradiation in the p53 $3^{+/-}$mice of the BALB/cHeA $\times$MSM/Ms background. The singly heterozygous $p 53^{+/-}$mice subjected to $\mathrm{X}$-irradiation developed mammary carcinomas at around 25 weeks of age, and the final incidence of mammary carcinomas at 39 weeks was $31 \%$ (19 out of 61 ). The introduction of the heterozygous Atm knockout alleles into the background of the $p 53^{+/-}$genotype significantly increased the incidence of mammary carcinoma to $58 \%$ (32 out of 55) and increased the average number of mammary carcinomas per mouse. However, introduction of Atm alleles did not change the latency of development of mammary carcinoma.

Conclusion Our results indicate a strong enhancement in mammary carcinogenesis by Atm heterozygous deficiency in $p 53^{+/-}$mice. Thus, doubly heterozygous mice represent a useful model system with which to analyze the interaction of heterozygous genotypes for p53, Atm and other genes, and their effects on mammary carcinogenesis.

\section{Introduction}

Ataxia-telangiectasia is an autosomal-recessive disease that affects neuro-immunologic functions, and is associated with increased susceptibility to malignancy, chromosomal instability and hypersensitivity to ionizing radiation
$[1,2]$. ATM (ataxia-telangiectasia mutated) heterozygous deficiency has been proposed to increase susceptibility to breast cancer [3-7]. However, those early studies were limited by the lack of reliable assays with which to identify carriers [8]. In fact, in a later study a lack of association of 
heterozygous ATM mutations with early onset of breast cancer was found [9]. More recent epidemiological studies suggested that missense mutation in the ATM gene, rather than a protein-truncating mutation, which accounts for the majority of mutations in patients with ataxia-telangiectasia, confers increased risk for breast cancer [10]. Thus, cancer risk in ATM heterozygotes varies depending on the mutation type (i.e. some missense-type mutations are associated with early onset of breast carcinoma whereas truncation-type mutations are not) $[11,12]$. Recently, epidemiological studies on excess risk for breast cancer in ATM heterozygosity were reported [13].

In experimental animals, no tumours were observed in Atm heterozygous mice carrying a knockout null allele of Atm [14]. In contrast, Atm knock-in heterozygous mice harbouring an in-frame deletion corresponding to the human mutation exhibit increased susceptibility to a wide variety of tumours [14]. Thus, data in humans and mice suggest that the type of Atm mutation determines susceptibility to cancer in heterozygous individuals. Heterozygosity for a null knockout allele of Atm in mice and protein-truncating alleles of ATM in humans was thought not to increase susceptibility to mammary cancer. On the other hand, haploinsufficiency at the Atm gene has a phenotype of increased sensitivity to ionizing radiation in mice [15].

In contrast to the Atm gene, the $p 53$ null allele exhibits haploinsufficiency for the development of tumours in mice, mainly lympho-haematopoietic malignancies $[16,17]$. The $p 53$ heterozygotes of BALB/c genetic background develop mammary tumours [18-20]. Mice doubly null for the $p 53$ and Atm genes were reported to exhibit a dramatic acceleration in tumour formation relative to singly null mice, indicating that the genes cooperate in a significant manner to prevent tumourigenesis [21]. However, the authors noted no mammary carcinoma in any of the four genotypes studied $\left(\mathrm{p} 53^{+/+} \mathrm{Atm}^{-/}, \mathrm{p} 53^{+/-} \mathrm{Atm}^{-/}, \mathrm{p} 53^{-/} \mathrm{Atm}^{+/}\right.$, and $\mathrm{p} 53^{-/}$ $\left.A t m^{-/}\right)$. Thus, the significance of haploinsufficiency of the Atm null allele in mammary carcinogenesis is obscure at present.

In order to determine the effect of Atm heterozygous deficiency on mammary tumourigenesis, we generated a series of $A \mathrm{tm}^{+/-}$mice on the background of $p 53^{+/-}$mice with a certain predisposition to spontaneous development of mammary carcinomas, and we examined the development of tumours after $\mathrm{X}$-irradiation. Our results indicate a strong enhancement of mammary carcinogenesis in the Atm heterozygous deficient mice under the $p 53$ heterozygous deficiency.

\section{Materials and Methods \\ Mice}

The $p 53$ targeted allele generated by Donehower and coworkers [22] was introduced into the BALB/cHeA mouse at The Netherlands Cancer Institute (Amsterdam). The p53 heterozygous deficient mice $\left(p 53^{+/-}\right)$were repeatedly backcrossed to BALB/cHeA mice more than 30 times, and maintained at the animal facility of Osaka Prefecture University. The Atm targeted mouse (129/SvEv-Atm ${ }^{\text {tm1Awb/+ }}$ mouse) was originally generated in the Jackson Laboratory [23]. The Atm heterozygous deficient mice $\left(\mathrm{Atm}^{+/-}\right)$were repeatedly backcrossed more than 10 times to MSM/Ms mice. The BALB/cHeA-p53+/- mice were crossed with $\mathrm{MSM} / \mathrm{Ms}-$ Atm $^{+/-}$mice, and females of the $\mathrm{F}_{1}$ progeny $\left([\mathrm{BALB} / \mathrm{cHeA} \times \mathrm{MSM} / \mathrm{Ms}] \mathrm{F}_{1}\right)$ with four genotypes (i.e. p53 ${ }^{+/-} \mathrm{Atm}^{+/-}, \mathrm{p5} 3^{+/-} \mathrm{Atm}^{+/+}, \mathrm{p53^{+/+ }} \mathrm{Atm}^{+/-}$and $\mathrm{p53^{+/+ }}$ $A t \mathrm{~m}^{+/+}$) were used in the experiments. The conditions for breeding were described previously [24].

\section{X-irradiation}

Mice were exposed at 5 weeks of age to X-rays (5 Gy; 260 $\mathrm{kV}, 12.0 \mathrm{~mA}, 0.3 \mathrm{~mm} \mathrm{Cu}+0.5 \mathrm{~mm} \mathrm{Al} \mathrm{filter;} 0.5 \mathrm{~Gy} / \mathrm{min}$ ) from an X-ray generator (Radioflex 350; Rigaku Industrial Co., Takatsuki, Japan). All animal experiments were carried out in accordance with the standards relating to the care and management of experimental animals (Japan) and Osaka Prefecture University's guidelines for animal care and use.

\section{Histopathological examination}

Moribund mice were killed by cervical dislocation for autopsy. In cases of thymic lymphoma, the enlarged thymuses were examined as previously described [25]. In tumour-bearing mice the tumours were fixed in 10\% buffered formalin, processed histologically, and stained with haematoxylin and eosin. The processed tumour specimens were evaluated by medical and veterinary pathologists using the Annapolis guidelines established by Cardiff and coworkers [26].

\section{DNA isolation and genotyping}

Normal and mammary carcinoma tissues were removed. Isolation of DNA, PCR amplification, electrophoresis of PCR products and assessment of allelic losses were performed according to a procedure described previously [24]. Genotypes for the wild-type and targeted alleles of p53 and Atm genes were determined by analyzing the PCR products for these alleles. Amplification for the $p 53$ alleles was done as described elsewhere [27]. The wild-type and the targeted alleles of the $p 53$ gene were amplified by PCR using primers p53-4F (5'-CGACCTCCGTTCTCTCTCCTCTCTT-3') and p53-6R (5'-AGACGCACAAACCAAAACAAAATTACA-3'), and primers p53-NF (5'GCCTTCTATCGCCTTCTTGACGAGT-3') and p53-6R, respectively. Similarly, amplification of the wild-type and the 
Figure 1
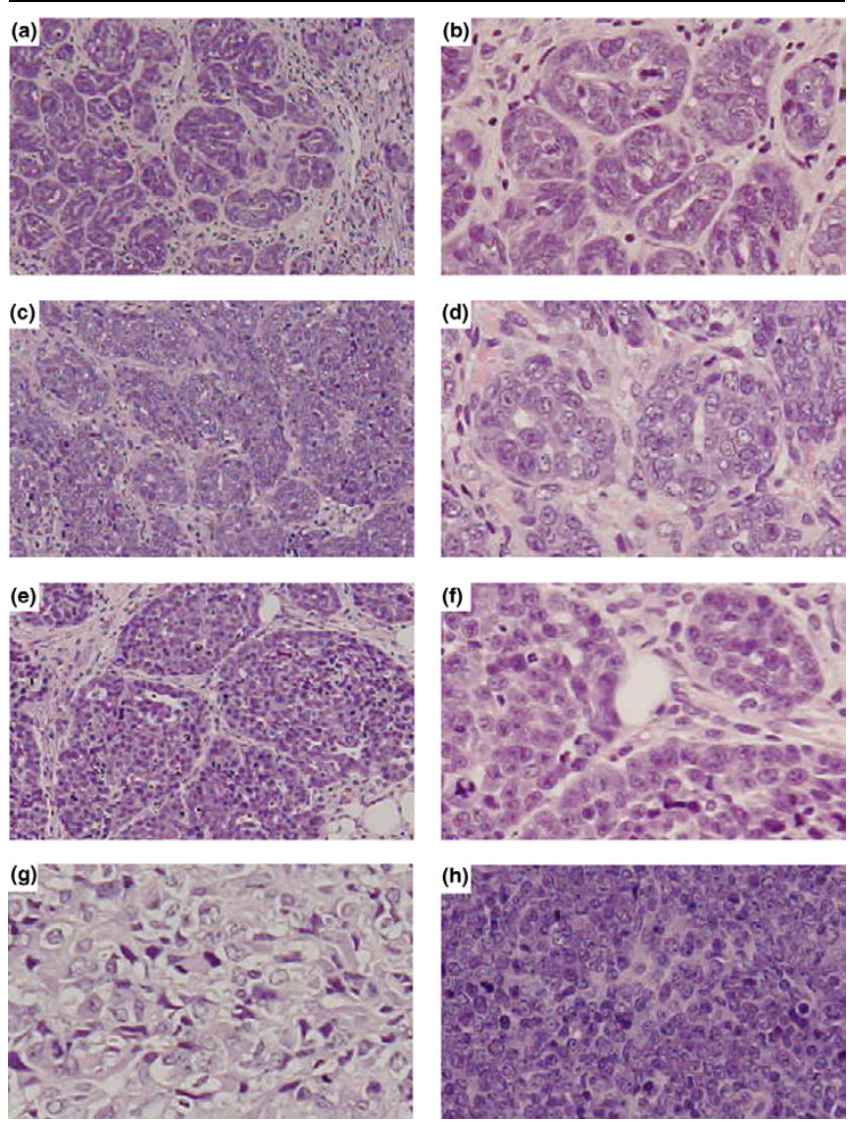

Histopathology of tumours in (BALB/cHeA $\times \mathrm{MSM} / \mathrm{Ms}) \mathrm{F}_{1}$ mice with genotypes $p 53^{+/-} \mathrm{Atm}^{+/-}, \mathrm{p53^{+/- }} \mathrm{Atm}^{+/+}$or $p 53^{+/+} \mathrm{Atm}^{+/-}$. (a, b) Spontaneously developing mammary adenocarcinoma from $p 53^{+/-} \mathrm{Atm}^{+/-}$ mouse. (c, d) Mammary adenocarcinoma from X-irradiated $p 53^{+/-} \mathrm{Atm}^{+/}$ - mouse. (e, f) Mammary adenocarcinoma from X-irradiated $p 53^{+/-} \mathrm{Atm}^{+/}$ + mouse. (g) Osteosarcoma observed in nonirradiated $p 53^{+/-} \mathrm{Atm}^{+/-}$ mouse. (h) Thymic lymphoma from $p 53^{+/+} A t m^{+/-}$mouse exposed to $X$ rays. Panels a, c and e: 40x. Panels b, d, f, g and h: 100x.

targeted allele of the Atm gene were performed by using primers IMR0640F (5'-GCTGCCATACTTGATCCATG-3') and IMR0641R (5'-TCCGAATTTGCAGGAGTTG-3'), and primers IMR0640F and AtmNeo410R (5'-CGGTGGATGTGGAATGTGTG-3'), respectively.

\section{Statistical analysis}

Statistical significance was evaluated for the incidence of mammary carcinoma and number of carcinomas per mouse by $\chi^{2}$ analysis and Mann-Whitney U-test, respectively. Comparison of latency in mammary carcinoma development was examined by unpaired Student's t-test.

\section{Results and discussion Histopathological features of tumours developed in $F_{1}$ mice doubly heterozygous for $p 53$ and Atm null alleles} Mammary carcinomas occurred in BALB/c mice of the $p 53^{+/-}$genotype, and tumours of similar macroscopic mor- phologies were also observed in the (BALB/c $\times \mathrm{MSM} /$ $M s) F_{1}-p 53^{+/-}$mice. The histological features of these tumours in the mammary glands are shown in Fig. $1 \mathrm{a}, 1 \mathrm{~b}, 1 \mathrm{c}, 1 \mathrm{~d}, 1 \mathrm{e}, 1 \mathrm{f}$, which indicates that they are adenocarcinomas. The histopathology of the tumours in nonirradiated mice (Fig. 1a,1 b) exhibited more hyperplastic lesions than did those in irradiated mice (Fig. 1c,1d,1e,1f), but basically there were no marked differences between the two groups. There was also no remarkable difference in histopathological features between $\mathrm{Atm}^{+/-}$(Fig. 1c,1d) and $\mathrm{Atm}^{+/+}$mice (Fig. 1e,1f) in the irradiated groups. These tumours formed glands lined by highly pleomorphic cells exhibiting frequent mitosis, and were classified as glandular adenocarcinomas, high grade according to the Annapolis Pathology Classification [26].

Lymphomas (Fig. 1g), mainly thymic lymphomas, were efficiently induced by exposure to X-rays, regardless of $p 53$ and Atm genotype, although only a few lymphomas were observed in nonirradiated mice. Ovarian carcinomas, osteosarcomas (Fig. 1h) and hepatomas developed spontaneously. Squamous cell carcinomas, basal cell carcinomas, histiocytic sarcomas and granulocytic leukaemias were also observed in irradiated mice.

\section{Spontaneous tumour development in mice with four genotypes for $p 53$ and $\mathbf{A t m}$}

Twenty-eight $\mathrm{p53^{+/- }} \mathrm{Atm}^{+/}, 22 \mathrm{p53^{+/- }} \mathrm{Atm}^{+/+}, 11 \mathrm{p53^{+/+ }}$ $\mathrm{Atm}^{+/-}$and $25 \mathrm{p53}^{+/+} \mathrm{Atm}^{+/+}$mice were examined for spontaneous development of tumours until age 26 months (113

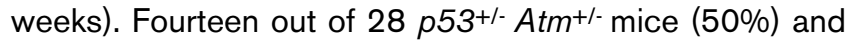

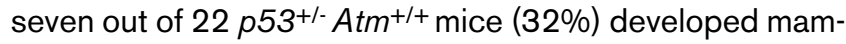
mary carcinomas during the period of observation (Table 1 , Fig. 2). The incidence of mammary carcinomas in $p 53^{+/-}$

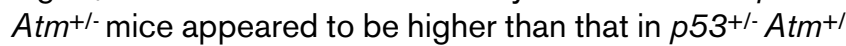
+ mice, but the incidences did not differ significantly between $\mathrm{Atm}^{+/-}$and $\mathrm{Atm}^{+/+}$genotypes ( $P=0.32$, by Fisher's exact probability test). Among the tumours that developed in the $p 53^{+/-}$mice, mammary carcinoma were the most common. These mammary carcinomas were mainly observed at 41-77 weeks after birth (Fig. 2). No significant difference in latency in the nonirradiated groups was observed between doubly heterozygous mice and $p 53$ singly heterozygous mice $(P=0.47$, by unpaired Student's t-test). None of $11 \mathrm{p53}^{+/+} \mathrm{Atm}^{+/-}$mice and $25 \mathrm{p5}^{+/+} \mathrm{Atm}^{+/}$ + mice developed mammary carcinomas. Several lymphomas and a few other tumours developed in the four genotypes (Table 1). Thus, mammary carcinoma development depended strongly on $p 53$ heterozygous deficiency in $(\mathrm{BALB} / \mathrm{c} \times \mathrm{MSM} / \mathrm{Ms}) \mathrm{F}_{1}$ mice, and $p 53^{+/-}$mice of both $\mathrm{Atm}^{+/+}$and $\mathrm{Atm}^{+/-}$genotypes developed mammary carcinoma. 
Table 1

Incidence of tumours developing spontaneously in (BALB/cHeA $\times$ MSM/Ms) $F_{1}$ female mice that were heterozygously deficient for p53 and/or Atm genes

\begin{tabular}{|c|c|c|c|c|}
\hline \multirow[t]{2}{*}{ Genotypes } & \multicolumn{2}{|c|}{$p 53^{+/-}$} & \multicolumn{2}{|c|}{$p 53^{+/+}$} \\
\hline & $\operatorname{Atm}^{+/-}(n=28)$ & $\operatorname{Atm}^{+/+}(n=22)$ & $\operatorname{Atm}^{+/-}(n=11)$ & $\mathrm{Atm}^{+/+}(n=25)$ \\
\hline Mammary carcinoma & $14(50 \%)^{a}$ & $7(32 \%)$ & $0(0 \%)$ & $0(0 \%)$ \\
\hline Lymphoma & $3(11 \%)$ & $3(14 \%)$ & $2(18 \%)$ & $4(16 \%)$ \\
\hline Ovarian carcinoma & $1(4 \%)$ & $1(5 \%)$ & $0(0 \%)$ & $1(4 \%)$ \\
\hline Osteosarcoma & $1(4 \%)$ & $0(0 \%)$ & $0(0 \%)$ & $0(0 \%)$ \\
\hline Hepatoma & $1(4 \%)$ & $0(0 \%)$ & $0(0 \%)$ & $0(0 \%)$ \\
\hline Number of mammary carcinomas/mouse ${ }^{b}$ & $14 / 28(0.50)$ & $7 / 22(0.32)$ & $0 / 11(0.00)$ & $0 / 25(0.00)$ \\
\hline
\end{tabular}

aNumber of mice with tumours. ${ }^{\mathrm{b}}$ Total number of mammary carconomas developing in mice with given genotypes/number of mice examined; numbers in parentheses are average numbers of tumours per mouse.

Figure 2

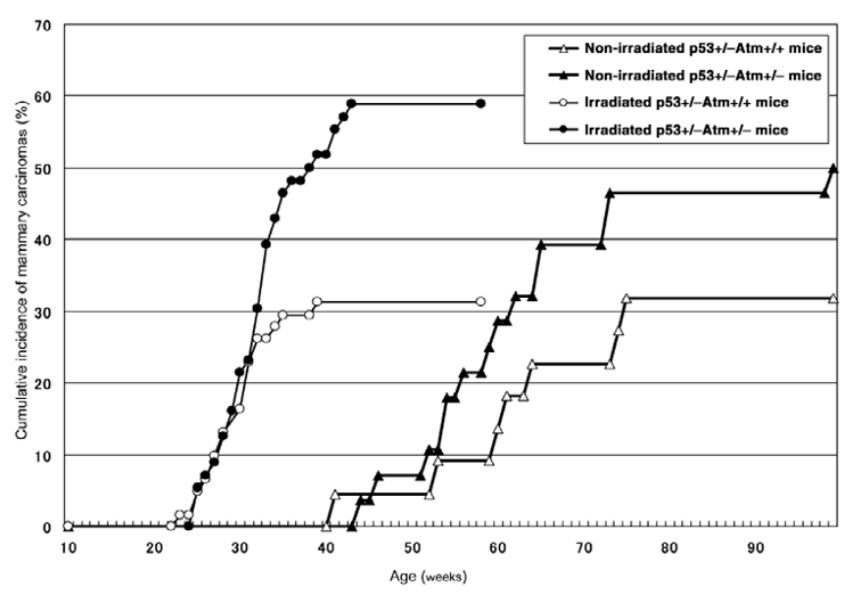

Cumulative incidence of mammary carcinomas in irradiated and nonirradiated $(\mathrm{BALB} / \mathrm{cHeA} \times \mathrm{MSM} / \mathrm{Ms}) \mathrm{F}_{1}$ mice with $p 53^{+/-} \mathrm{Atm}^{+/-}$or $p 53^{+/-}$ $\mathrm{Atm}^{+/+}$genotype.

\section{Enhancement of mammary carcinogenesis in Atm heterozygous deficient mice by $X$-irradiation}

To test the effect of haploinsufficiency of the Atm gene on mammary carcinogenesis after $\mathrm{X}$-irradiation in $p 53^{+/-}$mice,

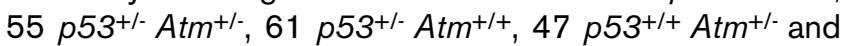
$53 \mathrm{p53}^{+/+} \mathrm{Atm}^{+/+}$mice (for a total of 216 mice) were exposed to X-rays (5 Gy) at age 5 weeks. Only one out of

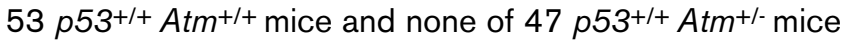
developed mammary carcinoma, indicating that almost all $p 53^{+/+}$mice fail to develop mammary carcinomas, despite $X$-irradiation and irrespective of Atm gene status. In contrast, 32 out of $55 \mathrm{p53}+/ \mathrm{Atm}^{+/-}$mice (58\%) and 19 out of $61 \mathrm{p53}^{+/-} \mathrm{Atm}^{+/+}$mice (31\%) developed mammary carcinomas (Table 2, Fig. 2). The proportion of mice developing mammary carcinomas in the $p 53^{+/-} \mathrm{Atm}^{+/-}$group was significantly greater than that in the $p 53^{+/}-\mathrm{Atm}^{+/+}$group $(P=$ 0.0034 , by $\chi^{2}$ test). A total of 52 mammary carcinomas developed in $55 \mathrm{p53}^{+/-} \mathrm{Atm}^{+/-}$mice (average number of mammary carcinomas $/$ mouse $=0.95$ ), whereas 28 mammary carcinoma developed in $61 \mathrm{p53}^{+/-} \mathrm{Atm}^{+/+}$mice (average number of mammary carcinomas/mouse $=0.46$; Table 2 ). The average number of mammary carcinomas per mouse in the $p 53^{+/-} \mathrm{Atm}^{+/}$group was significantly greater than that in $p 53^{+/-}$Atm $^{+/+}$mice $(P=0.0052$, by MannWhitney U-test). Thus, Atm heterozygous deficiency enhanced development of mammary carcinoma in irradiated $p 53$ heterozygous knockout mice. Spring and coworkers [14] observed no tumours in Atm knockout (Atm ${ }^{+/-}$) heterozygous mice. Mice bearing a knockout allele of Atm and humans carrying a mutant allele of truncated type in the ATM gene have been shown not to have obviously elevated susceptibility to mammary carcinogenesis. Our findings show that heterozygosity for a null knockout allele of Atm enhances mammary carcinogenesis under $p 53^{+/-}$status, although the Atm mutation is not a dominant-negative type. Heterozygous deficiency of p53 might make clear the effect on mammary carcinogenesis of haploinsufficiency in the Atm gene.

These mammary carcinomas were observed significantly earlier (at 18-38 weeks after irradiation; i.e. 23-43 weeks of age) than in the nonirradiated group (age 41-75 weeks; Fig. 2). In particular, mammary carcinomas frequently developed 23-28 weeks after irradiation. The mean ( \pm standard deviation) latency periods were $32.6 \pm 4.8$ and $29.8 \pm 3.6$ weeks in $p 53^{+/-} \mathrm{Atm}^{+/-}$and $p 53^{+/-} \mathrm{Atm}^{+/+}$mice, respectively. Thus, $\mathrm{X}$-irradiation at 5 Gy at age 5 weeks considerably shortened the latency period of mammary carcinoma development in these two groups with different genotypes. As shown in Tables 1 and 2, the incidences of mammary carcinoma in $\mathrm{p53}^{+/-} \mathrm{Atm}^{+/-}$mice were 58\% (32 out of 55) and $50 \%$ (14 out of 28 ) in irradiated and nonirradiated groups, respectively; in $p 53^{+/-} \mathrm{Atm}^{+/+}$mice the incidence in the irradiated group was 31\% (19 out of 61 ) and that in the nonirradiated group was 32\% (7 out of 22 ). The incidence of mammary carcinoma for each genotype was similar 
Incidence of tumours in irradiated (BALB/cHeA $\times$ MSM/Ms) $F_{1}$ female mice that were heterozygously deficient for $p 53$ and/or $A$ tm genes

\begin{tabular}{|c|c|c|c|c|}
\hline \multirow[t]{2}{*}{ Genotypes } & \multicolumn{2}{|c|}{$p 53^{+/-}$} & \multicolumn{2}{|c|}{$p 53^{+/+}$} \\
\hline & $\operatorname{Atm}^{+/-}(n=55)$ & $\operatorname{Atm}^{+/+}(n=61)$ & $\operatorname{Atm}^{+/-}(n=47)$ & $\operatorname{Atm}^{+/+}(n=53)$ \\
\hline Mammary carcinoma & $32(58 \%)^{a^{*}}$ & $19(31 \%)$ & $0(0 \%)$ & $1(2 \%)$ \\
\hline Lymphoma & $24(44 \%)^{b}$ & $29(48 \%)$ & $26(55 \%)$ & $22(42 \%)$ \\
\hline Squamous cell carcinoma & $1(2 \%)$ & $1(2 \%)$ & $0(0 \%)$ & $0(0 \%)$ \\
\hline Histiocytic sarcoma & $1(2 \%) c$ & $0(0 \%)$ & $0(0 \%)$ & $0(0 \%)$ \\
\hline Basal cell carcinoma & $0(0 \%)$ & $1(2 \%)$ & $0(0 \%)$ & $0(0 \%)$ \\
\hline Granulocytic leukaemia & $0(0 \%)$ & $1(2 \%)$ & $0(0 \%)$ & $0(0 \%)$ \\
\hline Ovarian carcinoma & $0(0 \%)$ & $1(2 \%)$ & $0(0 \%)$ & $0(0 \%)$ \\
\hline Nonthymic lymphoma (NOS) & $0(0 \%)$ & $1(2 \%)$ & $3(6 \%)$ & $0(0 \%)$ \\
\hline Solid tumour (NOS) & $1(2 \%)^{d}$ & $1(2 \%)$ e & $1(2 \%)$ & $1(2 \%)$ \\
\hline Number of mammary carcinomas/mouse & $52 / 55(0.95)^{\star \star}$ & $28 / 61(0.46)$ & $0 / 47(0.00)$ & $1 / 53(0.02)$ \\
\hline
\end{tabular}

aNumber of mice with tumours; percentage in parenthesis is the proportion of mice developing mammary carcinoma. ${ }^{b}$ Three animals developed both lymphomas and mammary carcinoma. 'One animal developed both histiocytic sarcoma and mammary carcinoma. dTumour in abdomen. eTotal number of mammary carcinomas developing in mice with given genotypes/number of mice examined; numbers in parentheses are average numbers of tumours per mouse. ${ }^{*}$ The proportion of mice developing tumours is significantly greater than that in $p 53^{+/-} \mathrm{Atm}^{+/+}$mice $(P=0.0034$ by $\mathrm{c}^{2}$ test). ${ }^{\star \star}$ The average number of tumours/mouse is significantly greater than that in $p 53^{+/-} \mathrm{Atm}^{+/+}$mice $(P=0.0052$ by Mann-Whitney U-test). NOS, not otherwise specified.

between irradiated and non-irradiated groups. Thus, irradiation may not elevate the incidence of the tumours.

Altogether, irradiation markedly hastened mammary carcinoma development in the $p 53^{+/-}$mice, in which mammary carcinomas developed spontaneously. Furthermore, irradiation also induced lymphomas, mainly thymic lymphomas, in all four genotypes of mice. The incidence of the lymphomas did not differ significantly among the four groups, with different genotypes for $p 53$ and Atm genes. A high incidence of thymic lymphoma was observed in previous studies performed using $p 53$ heterozygous deficient $F_{1}$ mice $[17,28]$. In the present study an extremely high incidence of tumours, most of which were mammary carcinomas and thymic lymphomas, was observed in irradiated $p 53^{+/-} \mathrm{Atm}^{+/}$ - mice.

\section{Status of wild-type alleles of p53 and Atm in mammary carcinoma}

The wild-type alleles of the $p 53$ and Atm genes were examined in mammary carcinoma tissue from heterozygous mice. The wild-type $p 53$ allele was lost in 25 (96\%) out of 26 mammary carcinomas from irradiated $p 53^{+/-}$mice and in all of 15 mammary carcinomas from nonirradiated $p 53^{+/-}$ mice, regardless of Atm gene status. Only one mammary carcinoma in irradiated $p 53^{+/+} A t m^{+/+}$mice (Table 2) was found to retain the $p 53$ wild-type allele. On the other hand, wild-type Atm allele was preserved in all of 17 mammary carcinomas from irradiated $\mathrm{Atm}^{+/-}$mice and in all of 10 mammary carcinomas from irradiated $\mathrm{Atm}^{+/+}$mice, regard- less of p53 gene status. Wild-type Atm allele was also retained in nine out of 10 mammary carcinomas from nonirradiated $\mathrm{Atm}^{+/-}$mice and in all of five mammary carcinomas from nonirradiated $\mathrm{Atm}^{+/+}$mice. These results suggest that the homozygous loss of the $p 53$ allele was a necessary condition for the development of mammary carcinomas, whereas the Atm null allele exhibited haploinsufficiency.

Haploinsufficiency for tumour development was reported for the Nbn knockout mice, the mouse homologue of NBS1. Heterozygosity for the Nbn knockout allele rendered the mice susceptible to tumour development, yet the $\mathrm{Nbn}$ wild-type allele was fully retained in all 12 tumours examined [29]. $p 27$ heterozygotes are also predisposed to tumours in multiple tissues when challenged with irradiation or a chemical carcinogen, and in the developed tumours the remaining wild-type allele is neither mutated nor silenced, indicating that p27 is haploinsufficient for tumour suppression [30]. In that study, heterozygous Atm knockout enhanced mammary carcinoma development in p53-heterozygous deficient mice, but the effect of Atm deficiency was not as profound. A previous study showed that heterozygosity for the Atm knockout allele did not enhance tumour development but that dominant-negative type missense mutations in the Atm gene did [14]. In humans, heterozygosity of the truncation-type mutations, which represent the majority of Atm mutations that occur in humans, had no effect on carcinogenesis, suggesting that enhancement in tumourigenesis depends strongly on mutation type. However, in the present study we demonstrated 
that haploinsufficiency does occur for the Atm null allele in combination with heterozygous deficiency in the $p 53$ gene. The $p 53$ heterozygous deficient BALB/c mice, which developed mammary carcinomas early and efficiently, may represent a useful model for the study of effects of genes other than Atm on mammary carcinogenesis. $\mathrm{F}_{1}$ mice between different subspecies may also provide an experimental system for precise genome-wide allelotype analysis of genes that cooperate with $p 53$.

\section{Conclusion}

Tumourigenesis is strongly enhanced in mice with homogeneous deficiency in the p53 or Atm gene. In the present study we tested the effect of haploinsufficiency of the Atm gene on mammary tumourigenesis after $\mathrm{X}$-irradiation in $p 53^{+/-}$mice of the BALB/cHeA $\times$MSM/Ms background. Singly heterozygous $p 53^{+/-}$mice $\mathrm{X}$-irradiated (5 Gy) at age 5 weeks developed mammary carcinomas at around 25 weeks of age, and the final incidence of mammary carcinoma at 39 weeks was 31\% (19 out of 61 ). Introduction of the heterozygous Atm alleles into the background of the $p 53^{+/-}$genotype significantly increased the incidence of mammary carcinomas to $58 \%$ (32 out of 55 ) and increased the average number of mammary carcinomas per mouse. However, it apparently did not change the latency of mammary carcinoma development. In nonirradiated mice, intro-

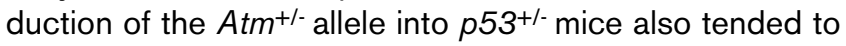
increase spontaneous incidence of mammary carcinoma. In contrast, almost none of the $p 53^{+/+}$mice developed mammary carcinoma, regardless of the Atm gene status and whether mice were subjected to irradiation. In almost all of the spontaneous and radiation-induced mammary carcinomas, the wild-type $p 53$ allele was found to be lost whereas the wild-type Atm allele was retained, suggesting haploinsufficiency of the latter gene in mammary carcinoma development. Thus, doubly heterozygous mice represent a useful model system with which to analyze the interaction of heterozygous genotypes for $p 53$, Atm and other genes and their effect on mammary carcinogenesis.

\section{Competing interests}

The author(s) declare that they have no competing interests.

\section{Authors' contributions}

SU carried out design of the study, observed mammary carcinoma development and other diseases, and drafted a manuscript. KF prepared tissue specimens and conducted histopathological examinations (veterinarian). SI carried out DNA isolation and genotyping of mice. NM carried out $X$ irradiation of mice and statistical analysis. MT performed DNA isolation and genotyping of mice. DH carried out production of heterozygous deficient mice. CS participated in designing the study and discussion of data on mammary carcinoma development. SH contributed to histopathologi- cal examination. SI conducted histopathological examinations (medical doctor). ON participated in discussion of data and contributed to preparation of the final manuscript. $\mathrm{MO}$ carried out design of the study and X-irradiation, and wrote the final manuscript. All authors read and approved the final manuscript.

\section{Acknowledgements}

We are grateful to Mr M lkeda and Mr U Ujihara for their skilful animal care. This study was performed in part by Grants-in-Aid for scientific research No. 13480172 (to MO) and No. 14580571 (to NM) from the Ministry of Education, Science, Sports and Culture of Japan, and a Grant-in-Aid from the Japan Atomic Energy Research Institute under contract to the Nuclear Safety Research Association.

\section{References}

1. Sedgewick R, Boder E: Ataxia-telangiectasia. In In Handbook of Clinical Neurology Edited by: Vinken P, Bruyn G, Klawans H. New York: Elsevier Scientific Publishers; 1991:347-423.

2. Lavin MF, Shiloh $\mathrm{Y}$ : The genetic defect in ataxia-telangiectasia. Annu Rev Immunol 1997, 15:177-202.

3. Swift M., Reitnauer P, Morrel D, Chase C: Breast and other cancers in families with ataxia-telangiectasia. N Engl J Med 1987, 316:1289-1294.

4. Swift M, Morrell D, Massey RB, Chase CL: Incidence of cancer in 161 families affected by ataxia-telangiectasia. $N$ Engl $\mathrm{J}$ Med 1991, 325:1831-1836.

5. Inskip HM, Kinlen LJ, Taylor AM, Woods CG, Arlett CF: Risk of breast cancer and other cancers in heterozygotes for ataxiatelangiectasia. Br J Cancer 1999, 79:1304-1307.

6. Geoffroy-Perez B, Janin N, Ossian K, Lauge A, Croquette MF, Griscelli C, Debre M, Bressac-de-Paillerets B, Aurias A, Stoppa-Lyonnet $\mathrm{D}$, Andrieu N: Cancer risk in heterozygotes for ataxiatelangiectasia. Int J Cancer 2001, 93:288-293.

7. Olsen JH, Hahnemann JM, Borresen-Dale AL, Brondum-Nielsen K, Hammarstrom L, Kleinerman R, Kaariainen H, Lonnqvist T, Sankila $\mathrm{R}$, Seersholm N, et al:: Cancer in patients with ataxia-telangiectasia and in their relatives in the Nordic countries. $J$ Natl Cancer Inst 2001, 93:121-127.

8. Concannon P: ATM heterozygosity and cancer risk. Nat Genet 2002, 32:89-90.

9. FitzGerald MG, Bean JM, Hegde SR, Unsal H, MacDonald DJ, Harkin DP, Finkelstein DM, Isselbacher KJ, Haber DA: Heterozygous ATM mutations do not contribute to early onset of breast cancer. Nat Genet 1997, 15:307-310.

10. Sommer SS, Jiang Z, Feng J, Buzin CH, Zheng J, Longmate J, Jung $M$, Moulds J, Dritschilo A: ATM missense mutations are frequent in patients with breast cancer. Cancer Genet Cytogenet 2003, 145:115-120.

11. Gatti RA, Tward A, Concannon P: Cancer risk in ATM heterozygotes: a model of phenotypic and mechanistic differences between missense and truncating mutations. Mol Genet Metab 1999, 68:419-423.

12. Teraoka SN, Malone KE, Doody DR, Suter NM, Ostrander EA, Daling JR, Concannon P: Increased frequency of ATM mutations in breast carcinoma patients with early onset disease and positive family history. Cancer 2001, 92:479-487.

13. Bernstein JL, Seminara D, Borresen-Dale AL: Workshop on the epidemiology of the ATM gene: Impact on breast cancer risk and treatment, present status and future focus, Lillehammer, Norway, 29 June 2002. Breast Cancer Res 2002, 4:249-252.

14. Spring K, Ahangari F, Scott SP, Waring P, Purdie DM, Chen PC, Hourigan K, Ramsay J, McKinnon PJ, Swift M, et al.: Mice heterozygous for mutation in Atm, the gene involved in ataxia-telangiectasia, have heightened susceptibility to cancer. Nat Genet 2002, 32:185-190.

15. Barlow C, Eckhaus MA, Schaffer AA, Wynshaw-Boris A: Atm haploinsufficiency results in increased sensitivity to sublethal doses of ionizing radiation in mice. Nat Genet 1999, 21:359-360. 
16. Kemp CJ, Wheldon $T$, Balmain A: p53-deficient mice are extremely susceptible to radiation-induced tumorigenesis. Nat Genet 1994, 8:66-69.

17. Hong DP, Mori N, Umesako S, Song CW, Park YG, Aizawa S, Okumoto M: Putative tumor suppressor gene regions responsible for radiation lymphomagenesis in $\mathrm{F}_{1}$ mice with different p53 status. J Radiat Res 2002, 43:175-185.

18. Kuperwasser C, Hurlbut GD, Kitterell FS, Dickinson ES, Laucirica R, Medina D, Naber SP, Jerry DJ: Development of spontaneous mammary tumors in BALB/c p53 heterozygous mice. A model for Li-Fraumeni syndrome. Am J Pathol 2000, 157:2151-2159.

19. Backlund MG, Trasti SL, Backlund DC, Cressman VL, Godfrey V, Koller $\mathrm{BH}$ : Impact of ionizing radiation and genetic background on mammary tumorigenesis in p53-deficient mice. Cancer Res 2001, 61:6577-6582.

20. Mori N, Yamate J, Umesako S, Hong DP, Okumoto M, Nakao R: Preferential induction of mammary tumors in p53 hemizygous $\mathrm{BALB} / \mathrm{c}$ mice by fractionated irradiation of a sub-lethal dose of X-rays. J Radiat Res 2003, 44:249-254.

21. Westphal CH, Rowan S, Schmaltz C, Elson A, Fisher DE, Leder P: Atm and p53 cooperate in apoptosis and suppression of tumorigenesis, but not in resistance to acute radiation toxicity. Nat Genet 1997, 16:397-401.

22. Donehower LA, Harvey M, Slagle BL, McArthur MJ, Montogomery CA Jr, Butel JS, Bladley A: Mice deficient for $p 53$ are developmentally normal but susceptible to spontaneous tumours. Nature 1992, 356:215-221.

23. Barlow $C$, Hirotsune $S$, Paylor R, Liyanage M, Eckhaus M, Collins F, Shiloh Y, Crawley JN, Ried T, Tagle D, et al.: Atm deficient mice: a paradigm of ataxia telangiectasia. Cell 1996, 86:159-171.

24. Okumoto $M$, Song $C W$, Tabata $K$, Ishibashi M, Mori N, Park YG, Kominami R, Matsumoto Y, Takamori Y, Esaki K: Putative tumor suppressor gene region within $0.85 \mathrm{cM}$ on chromosome 12 in radiation-Induced murine lymphomas. Mol Carcinog 1998, 22:175-181.

25. Okumoto M, Nishikawa R, Imai S, Hilgers J: Genetic analysis of resistance to radiation lymphomagenesis with recombinant inbred strains of mice. Cancer Res 1990, 50:3848-3850.

26. Cardiff RD, Anver MR, Gusterson BA, Hennighausen L, Jensen RA, Merino MJ, Rehm S, Russo J, Tavassoli FA, Wakefield LM, et al.: The mammary pathology of genetically engineered mice: the consensus report and recommendations from the Annapolis meeting. Oncogene 2000, 19:968-988.

27. Mori N, Yamate J, Stassen AP, Oka S, Okumoto M, Tsubura A, Akamatsu T, Sakuma S, Demant P: Modulations of glucocorticoid-induced apoptosis linked to the $p 53$ deletion and to the apoptosis susceptibility gene Rapop-1 (radiation-induced apoptosis 1). Oncogene 1999, 18:4282-4285.

28. Matsumoto $Y$, Kosugi S, Shinbo T, Chou D, Ohashi M, Wakabayashi Y, Sakai K, Okumoto M, Mori N, Aizawa S, et al.: Allelic loss analysis of gamma-ray-induced mouse thymic lymphomas: two candidate tumor suppressor gene loci on chromosomes 12 and 16. Oncogene 1998, 16:2747-2754.

29. Dumon-Jones V, Frappart P-O, Tong W-M, Sajithlal G, Hulla W, Schmid G, Herceg Z, Digweed M, Wang Z-Q: Nbn heterozygosity renders mice susceptible to tumor formation and ionizing radiation-induced tumorigenesis. Cancer Res 2003, 63:7263-7269

30. Fero ML, Randel E, Gurley K, Roberts JM, Kemp CJ: The murine gene $p 27$ Kip1 is haplo-insufficient for tumor suppression. Nature 1998, 396:177-180. 